\title{
WAR DAMAGE AND NATIONALIZATION IN EASTERN EUROPE
}

\author{
Samuel Herman*
}

I

In assessing the consequences of modern war the economic history of Eastern Europe in the post World War II period is extremely significant. Five years after the end of World War II, it is Eastern Europe which has experienced the swiftest evolution in economic form. In varying degrees, Poland, Czechoslovakia, Yugoslavia, Rumania, Hungary, and Bulgaria have shifted from capitalistic to communistic economies. Behind this transformation was the impetus of World War II. The Russian revolution, itself, it should not be forgotten, occurred in the late stages of World War I. No symposium dealing with modern problems of war claims would seem complete without some discussion of modern war damage in its most generalized sense, i.e., the loosening and weakening of the basic economic structure of modern societies under the pounding of military and economic warfare and the revisionist policies of enemy occupations. The lesson of Eastern Europe is that economic reform is tremendously accelerated, nationalization ensues, and, given political pressures.generating from within a destroyed or injured economy, and simultaneously asserted from without, the form of the society is transformed.

Thus neither the legal, economic, nor political aspects of war damage to property can, in our time, be fully isolated or considered in a vacuum. Compensation for damage is, of course, the touchstone of the legal approach. War damage may have occurred on such a scale that compensation in the conventional sense cannot be practically entertained. Compensation, as an economic device for restoring economies, may be rejected by governments in the face of overwhelming compulsions to adopt alternative solutions. In the circumstances of World War II, given the magnitude of the injuries and wrongs to private individuals, the thoroughgoing overhauling of property rights perpetrated by the Nazi occupants of Eastern Europe, ${ }^{1}$ and the uniform policies adopted in the liberation and reconstruction period of I945r947, "war damage" moves away from "war claims" and merges with the fundamental political considerations of the economics of reconstruction. It cannot be divorced from the post-war reorientation of views concerning property rights and relations. Thus Poland and Czechoslovakia, facing similar problems of postwar reconstruction, quickly recognized the oneness of property rights, political

- Ph.B. 1929, J.D. 1931, University of Chicago. Member of the Illinois and District of Columbia bars. Until December, 1950, Assistant to the Legal Adviser for International Claims, Department of State. Contributor to legal, economic, and political science periodicals.

${ }^{2}$ See Raphael Lemkin, Axis Rule in Occupied Europe 36-49 (1944). "Social philosophers and statesmen must watch carefully the phenomenon of the destruction of the institution of private property in Europe in the present war, which may become even more extensive if the war is prolonged and mny prove significant for future developments in the post-war period." Id. at $4 \mathrm{~b}$. 
orientation, and economic planning. In the large they were considered aspects of one problem. This was true of the countries of Eastern Europe whether or not they were "enemy" or "allied" during World War II. Although faced by certain legal consequences of their participation in World War II, Rumania, Hungary, and Bulgaria, as enemy states, were faced with the same problem, and, it is worthy of note, progressed to the same basic communistic forms as Poland, Czechoslovakia, and Yugoslavia, allied states in the same war.

In this very broad context of war damage-namely, the destruction of property rights as well as physical property by the Nazis-more important, at the outset, than the physical reconstruction of war damaged properties was the governmental need ${ }^{2}$ to disentangle property rights, undo forced transfers of property compelled by the Nazi occupiers, and reestablish some semblance of property relationship more consistent with the political viewpoints of the liberated governments. The fact that the titles of many properties could not be restored because the former owners or their heirs were dead or missing faced the returning governments immediately. The fact that collaborators had succeeded, through Nazi intervention, to large holdings of properties also faced the liberated governments who could not, for obvious reasons, permit such holdings to be maintained. A vast aggregation of property rights in Nazi persons or governmental instrumentalities-a form of looting-necessitated divesting and redistribution of the property in the interests of the new governments. The forced evacuation of important areas in Czechoslovakia through the expulsion of the Sudeten Germans ${ }^{3}$ presented to the Czechoslovak government, headed by Dr. Benes, the problem of redistribution or state ownership of land and faced it with difficult questions as to whether and how new property rights were to be established. Similarly, in Poland, the administration of large areas of Eastern Germany conferred upon the new Poland through the Potsdam and Yalta agreements ${ }^{4}$ presented to the early democratic Polish government the problem of how and under what circumstances to redistribute the land and the properties of this wealthy area, or to set up state ownership and control, after forcing the evacuation of the German inhabitants. New territorial accretions to Yugoslavia ${ }^{5}$ involved similar considerations of population and property.

In situations such as these, evolving from World War II, and, in the context of this discussion, best considered as in the nature of reparation on a governmental level

\footnotetext{
2 Compare Inter-Allied Declaration Against Acts of Dispossession Committed in Territories Under Enemy Occupation and Control, Miscellaneous No. I (London, 1943).

${ }^{3}$ See Chapter XII, Protocol of the Proceedings, Aug. I, I945, The Berlin (Potsdam) Conference, as contained in A Decade of American Foreign Policy, I941-49, Sen. Doc. No. 123, 8ist Cong., rst Sess. (1949). "The Three Governments, having considered the question in all of its aspects, recognize that the transfer to Germany of German populations, or elements, thereof, remaining in Poland, Czechoslovakia and Hungary, will have to be undertaken." Id. at 45 .

'Id. at 43-44. For Protocol of Proceedings, The Crimean (Yalta) Conference, Feb. 4-ri, I945, see id. at 31 . About 40,000 square miles of Eastern Germany territory was placed under the administration of the Polish state; five to six million Germans were evacuated.

'See Section IV, Treaty of Peace with Italy, 1947 (Dep't State Pub. 2743, European Series 2I).
} 
for war damages, the new governments faced the necessity of intervening with respect to the property rights of individuals in the paramount interests of public order, security, and restoration of occupation economies on a new basis. Uniformly, both as to new territories and as to former territories under Nazi or puppet occupation, liberated governments, of necessity, assumed the initial role of Administrator or sequestrator of property rights, as the case might be. Presumably, this was a form of trust in which the eventual form of the property rights could follow the course of either economic necessity or political pressure. In fact it followed the course of both. The firm pre-war relationships of property titles and rights had been drastically modified by the.Nazi occupants to an unparalleled degree in the history of modern war. The end of the occupations and the withdrawal or evacuation of the Nazis and their collaborators from the territories and properties which they had seized or held, immediately loosened the entire structure of property rights in the territories of the Eastern European countries. The state intervened of economic necessity and perpetuated the process for political reasons. It is the purpose of this discussion to trace this development in some of its more important forms in the legislation of three of the Eastern European states-Poland, Czechoslovakia, and Yugoslavia.

The beginning of the process was liberation and the end of the Nazi-Fascist domination; the end was the total nationalization of the economies of the liberated countries. It is fair to state that in terms of the economic consequences of war this is the most significant of all of the results of that struggle. While the omnipresent Soviet power in Eastern Europe facilitated the eventual establishment of communist governments in the Eastern European countries, ${ }^{6}$ it is, of course, notable that the restored governments, with the exception of Yugoslavia, were not at the outset wholly communist. There was in the beginning, in 1945, the pervasive spirit of the Potsdam Agreement. Yet the economic need for intervention by the state in property rights faced the early governments and forced its accomplishment. Agrarian reform as a policy of government had existed in varying degrees of implementation in all of the Eastern European countries prior to "World War II. Distribution of the land. while slow and frequently ineffectual, had nevertheless been commenced after World War I. ${ }^{7}$ This slow pre-war agrarian reform received enormous impetus in Poland and Czechoslovakia under the early post-war political coloration of these then democratically orientated countries. If the law of a state is determined by its economics, it is significant that without exception the laws of the liberated democratic governments provided, directly or indirectly, for large measures of state intervention, ownership, and control. ${ }^{8}$ It is suggested that the Soviet Government, as-

\footnotetext{
- Dates of Communist ascendancy to power are as follows: Rumania, March 6, 1945; Yugoslavia, January 30, 1946; Bulgaria, July-November, 1946; Poland, February 6, 1947; Hungary, June I, 1947; Czechoslovalia, February 25, 1949.

${ }^{7}$ Doman, Postwar Nationalization of Foreign Property in Europe, 48 CoL. L. Rev. 1125, 1126 (1948).

${ }^{8}$ See as to Poland, Czechoslovakia, and Yugoslavia, Sections II-IV, infra.
} 
suming its desire to see communist governments in Eastern Europe, could not have failed to recognize that the inevitable consequence of the economic pressure for state intervention in countries that had been looted, corrupted, damaged, or destroyed by the Wehrmacht and the Nazi occupations and collaborators would be (were Soviet political and military pressure asserted at the proper times) the conversion of private enterprise and capitalistic forms, in the Eastern European states, to the economic sine qua non of a communist society-the total nationalization of the basic productive property of the state and the severe curtailment of virtually all property rights as they are known in Western states. It is permissible to wonder whether, to some degree, the early post-war experience of the Eastern European states did not remind the Soviets of Kerensky's brief experience, after World War hostilities ended in Russia, and prior to the Soviet seizure of power.

Total nationalization as it finally materialized in the Eastern European countries after World War II showed in its very form and nature the nexus with what, in its most generalized form, has been referred to in this discussion as "war damage." A generalized analysis of the basic principles and similarities of the eventual nationalization measures in Eastern Europe is made later herein. ${ }^{9}$ To the extent that Eastern European nationalizations differ from their best known historical predecessor, the Soviet nationalizations after the October Revolution of $19 \mathrm{I} 7$, they reflect the differences between World War I and World War II. Thirty years of Russian experience with both the political and economic consequences of total nationalization had intervened. It has been noted that agrarian reform had made measures of progress in Eastern non-communist countries in those thirty years. Measures of socialization and economic reform which, in all instances, fell short of total nationalization had occurred in Western European countries and in the United States in the r930's as a consequence of the Great Depression. Socialization of some sectors of the economy had occurred in both the Nazi and Fascist regimes of the r930's. But an important historical difference between the nationalization movements in the Eastern European countries and the Soviet nationalizations after World War I was the degree of acceptance by the Western states of post-World War II nationalizations. It is, of course, true that after the onset of the so-called "cold war," political resistance developed in the United States and elsewhere to the extension of nationalization in the Eastern European countries under the later communist regimes. A great difference, however, was that the post-World War II nationalization process was, at the outset, not considered as revolutionary but recognized, even by the friends of private enterprise, as probably economically necessary and politically unobjectionable. Thus, as will be seen, many measures in Czechoslovakia, later extended and accelerated by the communists, were launched, with full acceptance by the Western powers, under the early Benes regime. ${ }^{10}$ Nationalization was gradualistic, stemming

\footnotetext{
"Nationalization is treated in this article largely in terms of the relationship of "compensation" and "capacity to pay."

${ }^{10}$ See Section III, infra.
} 
step by step from pre-World War II beginnings, to war damage, enemy occupation, and post-war reconstruction. In this gradual process would the role of the state be, at some point, inhibited, restrained, or reversed in favor of private enterprise? This was one of the deeply perplexing questions which were asked in the early discussions which led eventually to the formulation and adoption of the Marshall Plan. It was recognized, in the pre-Marshall Plan period, that under the influence of Soviet power and pressure, and without outside economic aid, most of the European countries might be forced to carry through to total nationalization. It developed that the course which each country would take after the terrible cost of 'World War II, would, in large measure, be determined by whether or not the country joined the Marshall Plan program. The Eastern European countries did not. Their path led from the damage of the war to total nationalization, and thus the course of their economies became interwoven with political decision. In this view of the matter, what to do about "war damage" was governed by political as well as economic decisions. But the legal theory was also of great importance.

Law mixes with politics and economics in the formulation of basic problems after military destruction in modern war. Lawyers representing the interests of property holders consider war damage to be a compensable wrong committed against the property holder. Legal thinking, in such a context, is immediately concerned with the problem of compensation for property loss which, when the war damage is sufficiently extensive, becomes, for an economy, a mixed problem of law and economics. This is also true of property loss suffered by virtue of nationalization or takings by the state. Some consideration of the manner in which the Eastern European countries looked and look upon the problem of compensation is thus highly relevant.

Soviet legal doctrine after World War I, although somewhat modified by the concessions to private enterprise made by Lenin, did not recognize that there was an obligation to pay compensation for the value of property expropriated or nationalized by the Soviet government. ${ }^{11}$ Internally, compensation was afforded by the Soviets to Soviet nationals in terms of social welfare rather than of legal obligation. ${ }^{12}$ Nor is it clear, after thirty-three years, that the Soviets have at any time recognized that there is an obligation under international law to pay just, adequate, and effective compensation for the property of foreign nationals expropriated by the Soviet government. $^{13}$ This failure clearly to recognize an obligation to compensate lay at the threshold of the non-recognition by the United States of the Soviet government in the period r9r7-r933. But after World War II there was no question of nonrecognition by the United States of the Eastern European governments on the score

\footnotetext{
${ }^{11}$ See Hazard, Soviet Property Law, 30 Cornelt L. Q. 466 (1945), for discussion of the Sovict theory.

${ }^{12}$ Compensation has been afforded as to property which Soviet law permits to remain in private ownership but subject to state controls.

${ }^{13}$ See note 18 , infra.
} 
of their nationalization programs. This recognition continues today ${ }^{14}$ under the total nationalization programs of the communist regimes in those countries. While the Soviets at various times discussed, on inter-governmental levels, the nationalization claims of foreign nationals, so far as is known no settlement agreements of this nature as between governments were ever reached. An agreement to settle such claims, reached in the exchange of notes in the 1933 recognition of the Soviet government by the United States, resulted in negotiations which reached an impasse in 1935, and were never resumed. ${ }^{15}$ Anglo-American legal thought could not, nor cannot, comprehend the Soviet position that an act of confiscation or nationalization without compensation was the restoration to the people of property stolen from them by their exploiters and not the stealing of property by the state from the people.

Failure to compensate foreign nationals affords diplomatic justification for challenging the action of nationalization. ${ }^{16}$ In the Soviet view, compensation to foreign nationals, if to be made at all, is in the interests of international economic relations rather than in discharge of an obligation by the Soviet government under interna: tional law. ${ }^{17}$ On this Soviet premise, compensation, if made at the inter-govern: mental level, could only be in terms of economic quid pro quos between the governments involved. In return for voluntary payment of compensation, the Soviets expected economic concessions. ${ }^{18}$ In brief, the Soviets would pay if it proved to their immediate economic advantage to pay.

The problem of compensation developed almost immediately in the nationalization programs of the Eastern European countries after World War II. Oddly enough for theory, the ultimate position of the Eastern European countries and of the Soviet government after World "War I proved identical. Compensation would be paid as between governments provided economic concessions were given by the government of the country whose nationals' property had been taken. The justification, however, for this was not as the Soviets had put it, that there was no legal obligation to pay. Eastern European countries recognized the legal obligation to

14 Diplomatic relations between the United States and Bulgaria were severed on February 20, 1950.

26. See Establishament of Diplonatic Relations With the Union of Soviet Sociazist Republics, 1933 (Dep't State, Eastern European Series, No. x). Under the so-called "Litvinoff Assignment" of November I6, 1933, certain claims of the Soviet Government as successor to prior Governments of Russia against American nationals were assigned to the United States "preparatory to a final settlement" of claims and counterclaims between the two governments. There has been no "final settlement." Some $\$ 7,000,000$ has been collected by the United States pursuant to the "Litvinoff Assignment."

${ }^{20}$ For a recent review of the authorities, see Rubin, Nationalization and Compensation: A Comparative Approach, i7 U. of CH. L. Rev. 458 (1950).

${ }_{17}$ On this the diplomatic documents published in 2 Foreign Relations of the United States: 1933 at $778-840$ (Dep't State, 1949), are illuminating.

${ }^{16}$ As quid pro quo for the settlement of claims of the United States, the Soviets expected credits or loans. The Soviets hoped to achieve two purposes: ( $x$ ) propagandistic: to make payments in an indirect or disguised manner which would permit the Soviet Union to deny that it was recognizing the validity of the nationalization claims of foreign nationals; and (2) economic: to obtain concessions and terms from the United States which it would be impossible for other claimant governments to extend to the Soviets thereby relieving the Soviets of the necessity of extending comity in claims settlements to all foreign governments. See note 17, supra. 
pay ${ }^{10}$ but justified the failure to pay compensation on the score of lack of capacity to pay. ${ }^{20}$ This lack of capacity to pay obviously stems from the premise of extensive war damage in World War II and the generally recognized necessity of restoring war damaged economies, given a condition of inadequate or partial war reparations only. This recognition of the legal obligation to compensate, both as to the nationalizing country's own nationals and as to nationals of foreign countries, is an interesting aspect of the gradualism after World War II. Local compensation remedies are provided for, without exception, in the nationalization legislation of the Eastern European countrics. It is doubtful whether these countries at any time realistically expected that the nationals of foreign countries would take advantage, to any great extent, of local remedies providing for compensation. In fact, the governments of Western nationals investing in Eastern European countries, have not recognized that such remedies, and the relief afforded, satisfy the standards of justice under international law. Compensation has thus far been made in a framework of overall settlements between governments. ${ }^{21}$ The fact that such settlements have been made after World War II and could not be made with the Soviet Union after World War $I$ is some indication of the changing international viewpoint caused by economic developments between the two wars and by the nature of World War II itself. It is significant, in evaluating the consequences of modern war, to note that not only have Western countries, in the midst of the "cold war," settled nationalization claims on mutually advantageous terms with Eastern European countries, but that they have recognized the right of the Eastern European countries to nationalize and gauge their obligations in terms of their capacity to pay. This acknowledgment that the legal obligations of the Eastern European countries are to be tested fundamentally by capacity to pay is, it is suggested, an outgrowth of the entire problem of reconstruction and reparation after World War II.

It is doubtful whether capacity to pay would have become a key concept were it not for the destruction caused by World "War II. Capacity to pay, between states, is a matter of meeting the recognized obligation to pay just, adequate, and effective compensation.

Local remedies available under the legislation of the Eastern European countries

${ }^{10}$ Thus as to Czechoslovakia, Paragraph 7 of Agreement on Commercial Policy Between the United States of America and Czechoslovakia (Treaty Ser. 1569) effective November 14, 1946, provides: "The Government of the United States and the Government of Czechoslovakia will make adequate and effective compensation to nationals of one country with respect to their rights or interests in properties which have been nationalized or requisitioned by the Government of the other country."

. As to Poland, see Dep'r State Press Release No. 935 (Dec. 27, 1946).

$\because$ This position was always taken, as will be seen, when foreign governments insisted on compensa. tion other than in local currency.

"21 Examples: Belgian-Czechoslovak, November, 1949 (settlement fund accumulated by deducting percentage of payment for imports from Czechoslovalia); British-Czechoslovak, September, 1949 (installment compensation with simultaneous trade agreement); British-Yugoslav, December 23, 1948 (simul. taneous trade agreement with schedules of imports and exports); United States-Yugoslav, July 19, 1948 (simultancous unblocking of Yugoslav assets in the United States); French-Czechosloval, August 6, r 948 (payment out of credit balance in favor of Czechoslovakia arising out of economic and financial relations between the two countries). 
provide for payment in local currency or payment in long-term bonds redeemable in local currency. ${ }^{22}$ One of the consequences of World War II was the extension of foreign exchange controls to almost all countries. ${ }^{23}$ Local currencies were universally blocked in the nationalizing countries. Foreign governments in espousing the claims of their nationals arising out of the nationalization of property interests contended that payment in local blocked currency did not constitute "effective" compensation, since a totally nationalized economy did not permit of private reinvestment in the country and, accordingly, local currency was of no practical utility to a foreign national, thereby making such "compensation" a nullity. The right of a government to control its currency has been internationally recognized ${ }^{24}$ and has been a prime reason for diplomatic espousal of nationalization claims and a stimulus to inter-governmental overall settlement. Inevitably, inter-governmental negotiators must consider the question of the capacity to pay by the nationalizing country, since the availability or non-availability of foreign exchange determines the possibility of "effective" compensation. The right to block currencies is explicitly recognized by the international community and the privilege of a country, whose economic condition does not so warrant, to make payments in foreign exchange is even curtailed by international agreement. ${ }^{25}$

The Eastern European countries have contended that the test of any obligation under international law must be realistic; that no country should be expected to meet an obligation which it is economically impossible for it to assume. The counter argument has been that no state has an international right to take property without providing prompt, adequate, and effective compensation and, given the absence of such compensation, the taking is a nullity. ${ }^{26}$ The nationalizing countries have claimed that the right of a state to expropriate property is an attribute of its sovereignty. The right of a state to block local currencies and otherwise engage in financial controls is, it has been contended, also an attribute of sovereignty. The simultaneous exercise of both powers nullifies neither. The requirement of "just, adequate, and effective compensation" originated in a time of widespread private property holdings and relatively limited property takings by the state. Such takings, commanding "prompt, adequate, and effective" compensation, were for police or public welfare purposes-such as expropriation of property for highways, schools, and the like. In such a period in the international community, the state was a minor factor in property holdings and the private individual the major factor. Accordingly, in the view of the Eastern European countries, the obligation to make "prompt, adequate, and effective" compensation was always correlative to a country's

22 Sec Sections II-IV, infra.

${ }^{23}$ See First Annual Report on Exchange Restrictions, International Monetary Fund (March I, I950).

${ }_{24}$ Cf. Rubin, supra note 16 , at $460-462$.

2" See Article 8, Section 2, Articles of Agreexient of the Internationat Monetary Fund 28-67 (Dep't State Pub. No. 2187, Conf. Series 55, 1944).

${ }_{20}$ Hyde, Compensation for Expropriation, 33 AM. J. INT'L L. 108, I12 (1939). 
capacity to pay or its capacity to raise the means of compensation by taxation or negotiable credit instruments. ${ }^{2 \pi}$ This, the Eastern European countries claimed, they could not do on the basis of the established doctrine of compensation because of the economic destruction and chaos caused by World War II and the "acceleration of history" thereafter. Can any modern state, particularly a state badly damaged by modern war, be required to pay prompt, adequate, and effective compensation to all former property holders where, in the exercise of its public policy, it nationalizes the entire economy? Did not the economic consequences of World War II make nationalization a reasonable exercise of public policy? Assuming such a state, in the exercise of its soverign power, establishes a basis of local currency payments adequate to meet, over a long period of time, compensation obligations, is it obligated to pay promptly in unblocked foreign exchange to foreign nationals? If the nationalizing state has no capacity to make such payment, especially where large scale foreign investment has existed on a pre-war basis and has been nationalized on a post-war basis, is a foreign government warranted in insisting on such compensation without entering into correlative and simultaneous economic agreements .whereby through loans, credits, or agreed trade turnover it is made possible for the nationalizing state to pay compensation in settlement? In brief, allied countries during World IWar II such as Czechoslovakia and Poland have taken the position that the international obligation to pay can be implemented only if the government insisting on the obligation makes it possible for the nationalizing government to pay. Could the United States, if it nationalized its. entire economy, pay "prompt, adequate, and effective compensation" to all holders of private property in the United States? An insistence upon the letter of the obligation in effect negated the international recognition of sovereign right to expropriate property. All inter-governmental settlements for the nationalizing of property after World "War II, where the East and West are involved, have been entered into on simultaneous conditions of economic aid or specified trade relations between the compensating and the compensated countries. ${ }^{28}$ In thus posing the question of who "compensates". whom, the Eastern European countries after World War II had, in practical effect, come very close to the Soviet position after World War I. The outstanding difference between World War I and World War II in this respect has been the recognition, by important countries of the West, of the practical logic of this position taken by Eastern European countries.

Given the foregoing, the fact that lump-sum inter-governmental settlements

${ }^{27}$ Cf. I L. F. L. Oppenheim, International LAw 318 (6th ed, Lauterpacht, 1947). "The rule is clearly established that a State is bound to respect the property of aliens. This rule is qualificd, but not abolished, by two factors: . . The second modification must be recognized in cases in which fundamental changes in the political system and economic structure of the State or far-rcaching social reforms entail interference, on a large scale, with private property. In such cases neither the principle of absolute respect for alien private property nor rigid equality with the dispossessed nationals offer a satisfactory solution of the difficulty. . It is probable that, consistently with legal principle, such solution must be sought in the granting of partial compensation."

see note $2 \pi$, supra. 
have been made by Eastern European countries is not surprising when to the factor of concomitant economic concession there is added the factor of the property damage of World War II. A lump-sum settlement is a negotiated settlement and does not mean the payment of Ioo per cent of the claims asserted or of their probable worth. And apart from the obligation to pay and the capacity to pay, there are important questions as to the values of the properties involved. A feature of war damage in World War II is that the total extent of the later nationalization obligation is minimized by reduction in valuations because of damage. Also, certain other simultaneous large scale penal confiscations by the nationalizing country are, under recognized principles of law, not subject to compensation. In Eastern European economic planning, if the amount of compensation payable for all properties taken is greatly reduced because there is no obligation for penal confiscation, it may be feasible to nationalize an entire economy. This is part of the pattern, it may be observed, adopted by the Soviets in the post-Revolution takings of property in the Soviet Union. The legal distinction between confiscation and nationalization has important economic consequences in assessing the burden of compensation that the state assumes to pay. To the extent that the state is free from the legal obligation to pay compensation, and from the moral and propaganda onus in failing to discharge its obligation, it is in a stronger position to operate a nationalized economy totally "owned" by the state. The Eastern European countries, it is submitted, found it possible to carry on nationalization programs, although assuming a burden of compensation, because in addition to the facts that World War II had made it cheaper to nationalize, and economic concessions and bargained reductions in cost could be obtained in the post-war period, they had, through penal measures, confiscated substantial amounts of property without an obligation to compensate.

In all of the Eastern European countries, and particularly in Poland, Czechoslovakia, and Yugoslavia, the liberated governments confiscated property holdings as penalties. As to this expropriation technique, the reported Nazi boast that whether Germany won or lost the war, Europe would never be the same again, has peculiar relevancy. The crimes set forth in immediate post-war legislation providing for the confiscation of property as penalty are many and the property takings were of far-ranging economic consequence. ${ }^{29}$ Because of the racial and other persecutions of the Nazis, many properties were found abandoned, taken under the administration of the state, and never returned, or returned for occupancy only, under conditions of nationalization. ${ }^{30}$ The takings of property held by Nazis or Nazi collaborators on penal grounds caused much economic wealth to fall in the hands of the sequestrating state. The evacuation of German or Volksdeutche populations from the territories of the liberated governments caused much property to come into the ownership of the state. Post-war taxes levied for punitive reasons or because of the cost of physical rehabilitation and reconstruction also caused property to revert to

${ }^{29}$ See Sections II-IV, infra.

${ }^{30}$ Ibid. 
the state. The value of the direct and indirect property takings of the Eastern European countries under circumstances in which compensation was not legally required by Western standards cannot be accurately stated but it is submitted that the amount was substantial and that "World War II not only furthered the economic need for nationalization but, in a very real sense, the nature of the war and its effect on property made it feasible for the state to commence total nationalization programs without assuming burdens of impossible compensation.

In this respect, an analysis of some of the relevant war damage, restitution, penal, and nationalization measures of three of the Eastern European countries-Poland, Czechoslovakia, and Yugoslavia-will afford illuminating insights.

$\because:$

II

Poland

The general principles discussed above may be considered in the light of the sequence of laws, decrees, and regulations promulgated in and with respect to Poland in the years 1944 to 1946 . It should be noted that the legislation and the regulations were enacted prior to the establishment of the present communist government in Poland. ${ }^{31}$

On August 3I, 1944, in promulgating a decree with respect to the administration of punishment to Nazi criminals and to Polish traitors, ${ }^{32}$ the Lublin Government designated as criminals persons acting on behalf of the German occupation authorities and prescribed as one of the penalties the confiscation of the entire property of the guilty person. The decree encompassed all activities of such persons from August 3r, I939, on. Similarly, a decree issued on September $6,1944{ }^{33}$ relating to agrarian reform, provided that apportionment of landed property without compensation to the owners should be made of the property of "citizens of the German Reich and Polish citizens of German nationality," of the property of persons guilty of treason to the state or of giving assistance to the occupation forces, or of the property of any person subject to the decree of August 3r, 1944, referred to above. In a decree of September $7, \mathrm{x}_{944}{ }^{34}$ establishing housing commissions to adjust the housing question because of war damage, destruction, and the necessity of mass resettlement, housing commissions were directed to give particular consideration to the claims of persons who acquired rights to houses before September 1 , 1939, and whose rights were later set aside by the occupation authorities.

In a law, dated May 6, $1945,{ }^{35}$ regarding abandoned and deserted property, provision was made for the restitution of property in Poland both movable and fixed, the possession of which was lost in connection with the war. It was provided, in general, that restitution would be granted if possession was lost as the result of

${ }^{31}$ February 6, 1947.

32 Journal of Laws of the Republic of Poland, Decree No. 16.

${ }^{53} I d$. Decree No. 17 . ${ }^{34}$ Id. Decree No. 18.

${ }^{25}$ Id., Law No. 17, Item 97 . 
abandonment, confiscation, agreement with the occupation authorities, or voluntary transfer, if the transfer was made to preserve the property from loss in connection with the war or the occupation. An Office of Temporary State Administration was created to manage abandoned and deserted property. ${ }^{36}$ Property of the German state not yet taken over by the Polish state, or its organs, passed into the administration of the state. ${ }^{37}$ A decree of March 8, 1946, provided a procedure for restitution of property belonging to persons who lost possession during World War II. The property of categories of Germans and others referred to in previous decrees would not be restituted to previous owners. ${ }^{38}$

In practice, from 1946 through 1949 , persons attempting to assert rights under the restitution decree of March 8, I946, faced increasing difficulties. Restitution of property rights to persecutees was hampered by the fact that many such claims involved assets of persons killed in the ghettos or in the German concentration and extermination camps in Europe. Such persons, considering their large numbers, had extensive property holdings in Poland; and considering the virtual extermination of the Jewish population of Poland, attempts to gain title to these properties usually required continuous search for relatives who might still be alive, and for death records and other vital statistics records, many of which were destroyed during the war. The obtaining of such necessary documentation involved considerable effort and expense, which in practice was very possibly greater than the value of the properties if recovered, and accordingly, rights to restitution were abandoned and the administration by the state resulted in property devolution to the state.

As time went on, restitution of property in Poland became less common, although the legal right, under the March 8, 1946, decree, to such restitution existed, because many of the small property holdings were, because of extensive war damage, reduced to only a fraction of their pre-war values. In many cases even if recovered by the former owners they would be valueless. Most of the buildings which were not completely destroyed during the war were damaged or suffered from pillage and lack of upkeep. ${ }^{39}$ Heavy expenditures would have to be met for reconstruction and repairs. Rentals were held at a low level by law and strict controls, and such rentals in any event were taxed to such an extent that the balance left little to the owners and was not sufficient to cover maintenance cost. Sales values became proportionately small, and in any event, the proceeds could not be withdrawn from Poland because of the currency restrictions established by Polish authorities. Accordingly, of the bulk of properties seized, confiscated, or acquired under forced transfers by the Nazi occupants, little, in fact, was returned to the previous owners on the pre-rg3g basis.

Restitution of property to previous owners did not encompass property which was either confiscated by Poland under previous decrees or nationalized by Poland under the Act of January 3, 1946, referred to later herein. The likelihood of former

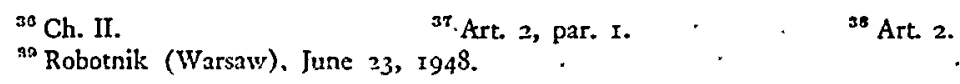


property owners asserting rights under the restitution decree would have been enhanced had war damage compensation been paid. A war reparations bureau attached to the Council of Ministries commenced registration of war damage by issue of questionnaires returnable not later than April $\mathrm{I}, 1947 .^{40}$ While the questionnaire covered all possible types of war damage in a most detailed fashion, the information gathered was considered to be for statistical purposes and did not insure the payment of compensation by the Polish government. The entire question of payment of compensation for war damage has been deferred, presumably until the coming into effect of German and Austrian peace treaties containing reparations provisions. Accordingly, as yet no compensation has been paid for war damage suffered in Poland.

In the tabulation of war damage loss, persons injured were permitted to state loss suffered because of personal damages, including among others, physical disability, mental disability, loss of life of the head of the family, and moral losses (such as national, racial, political persecutions). In connection with property losses, persons were permitted to state household and personal property damage, loss of livestock and vehicles, loss of real estate, and damage to industrial establishments, commercial enterprises, and independent occupations. Other losses listed related to expulsion, destruction; confiscation, and theft, non-payment of money due, losses in connection with insurance and mortgage claims resulting from the destruction of real estate, limitation of profits, and illegal deprivation of freedom. Provision was made, as to each item, for a statement of the amount requested for indemnity.

- Early in 1946 the Polish Provisional Parliament enacted a law ${ }^{41}$ nationalizing Poland's key industries, "in order to restore the Polish national economy, to insure the economic sovereignty of the state, and to improve the general standard of living." The law provided for the taking over of enterprises on two bases, first, without compensation, ${ }^{42}$ and secondly, subject to compensation. ${ }^{43}$ The Polish Ministry of Industry at the time of the promulgation of the law affirmed that the Polish Government had adopted the principle of compensation "although it burdens the whole state and delays reconstruction."44 The Minister of Industry stated, "I think I represent the whole nation when I say that just compensation should be paid to such an extent, in such form, conditions, and terms, that would not handicap the development of our economy."45

Categories of enterprises taken over, under the above law, by the state without compensation, for penal reasons, included the following: (I) Those owned by

\footnotetext{
${ }^{\circ}$ Effective April 1, 1947, the Ministry of Public Information was assigned problems in connection with damage which occurred on former Polish territory, the Ministry of Regained Territories was assigned war damage problems on former German territory, and the Central Planning Board was assigned the general problem as related to reparations and preparation of the German and Austrian treatics.

${ }^{4}$ Act of January 3, 1946, Journal of Laws of the Republic of Poland, No. 3, Item 17, effective February 5, 1946.

2 Art. 2 . ${ }^{43}$ Art. 3.

"Warsaw Radio, January 2, 1946, statement by Hilary Minc.

${ }^{45}$ See also, 15 DeP'T State Bull. 65I, 653 (1946).
} 
the German Reich and the former Free State of Danzig. (2) Those owned by the citizens of the above two states, excluding persons of Polish nationality or of other nationality persecuted by the Germans. (3) Those owned by German or Danzig legal persons excluding public bodies. (4) Those owned by companies controlled theretofore by the German or Danzig citizens or by German or Danzig military authorities. (5) Those owned by persons who fled to the enemy. ${ }^{46}$

In the light of the principle that compensation would be paid only to the extent that it would not overburden the Polish economy, the effects of World War II may be noted in the following economic factors to be taken into consideration under the law: first, the general decrease of the value of the national assets as a result of the war; second, the reduction in the value of the enterprise as a result of war and occupation from September 1939 to the date of nationalization; and third, reduction in compensation to the extent of investment in the enterprise after September I, 1939. ${ }^{47}$ In the so-called "recovered territories" (East German territory placed under Polish administration as the result of the Yalta and Potsdam Agreements) an aggrandizement of the role of the Polish Government very naturally occurred. The evacuation of the German population resulted in the establishment, by 1949, of almost 5,800 state-owned farms in that area. In some 18 months, there were resettled in the "recovered territories" over $3^{1 / 2}$ million Poles from central and eastern Poland, especially Poles from territories ceded to the Soviet Union. ${ }^{48}$ By the decree of November $13,1946{ }^{49}$ a national levy was imposed on private individuals, cooperatives, and state enterprises to raise some 13 billion zlotys for the reconstruction of the "recovered territories" by the Polish Government-i.e., repairing, on a governmental basis, without recourse to private compensation.

\section{III}

\section{Czechoslovakia}

World War II, for Czechoslovakia, is considered as having started on September 29, 1938, with the German invasion of the Sudetenland, and as having ended on May 19, 1945, with the first Benes decree invalidating legal transactions under the Nazi occupation. ${ }^{50}$ At the end of the war Czechoslovakia had suffered less physical damage to property than the other Eastern European countries. Nevertheless, the German occupations had taken over many Czech properties, including the two more important banks and all of their assets. The Nazis had acquired large property holdings through the confiscation of Jewish and foreign capital. Nazi collaborators

40 Art. 2, sec. I, Act of January 3, I946, supra note $4 \mathrm{~T}$.

${ }^{47}$ Art. 7 , sec. 5.

4. Rzeczpospolita' (Warsaw), November $15,1946$.

${ }^{40}$ Journal of Laws of the R'epublic of Poland, No. 6r, Item $34 \mathrm{r}$.

so Title: "On the invalidity of certain legal transactions concerning property, entered into during the period of bondage; and on the State administration of property belonging to Germans and Hungarians, traitors and collaborators, and certain organizations and institutions." CODE of Laws and ORdinances of trie Czechoslovak Republic, No. 5/45. 
had obtained large property holdings through forced transfers and the general pattern of German indirect looting had been carried on in a large scale. ${ }^{\text {o1 }}$

After the German surrender it was discovered that many enterprises crucial to the operation of the $\mathrm{Czech}$ economy were without owners or managers. In many instances management was taken over by workers' councils, later recognized by Czech law providing for state control of so-called "masterless enterprises" formerly owned by Germans, Hungarians, or Czech collaborators. ${ }^{52}$ In a decree of May I9, I945, ${ }^{53}$ nullifying transfers of property, "entered into or undertaken under pressure occasioned by enemy occupation or by national, racial or political persecution on or after September 29, I938," state administration was imposed on such properties "wherever this is necessary and essential in the interest of the continuity of production and economic life." In a Czechoslovak application of a principle which, as has been seen, was applied in Poland, the Benes government decreed that the following categories of persons were "nationally unreliable" and their property placed under state administration:

(I) Persons of German or Hungarian nationality.

(2) Persons who had engaged in activities generally understood to be collaborationist.

The decree listed a series of organizations in existence under the German occupation, and membership by Czechs in such organizations was considered automatically collaborationist. ${ }^{54}$ All companies and legal entities were considered to be "nationally unreliable" if their conduct furthered the German or Hungarian war effort or "other Fascist or Nazi aims." Cz5 Czechs were considered to be of "German or Hungarian nationality" who "at any census of the population taken since 1929 declared to belong to the German or Hungarian nationality." This would include virtually all of the population of the pre-war Sudeten areas of Czechoslovakia. The decree set up in detail the conditions under which state administration would operate $^{6 \tau}$ and resulted in the placing of a significant portion of the Czech economy under state control by the Benes government.

This immediate sequestration was followed by a set of decrees confiscating property outright and passing title thereto to the state. Thus, on June 21, 1945, it was decreed that all agricultural property owned by persons in the categories referred to in the earlier decrees cited above was to be confiscated immediately without compensation. ${ }^{58}$

It was provided that confiscated land would be administered by an agency of government until the land was redistributed. ${ }^{69}$ Likewise, in a decree of October

${ }^{81}$ See note I stipra.

s3 Ibid.

${ }^{85}$ Art. 5 .

${ }^{87}$ Art. $15 \mathrm{et} \mathrm{seq.}$ $7 / 45$.

Presidential Decree No. 12. Code of Law and ORdinances of the Czechostovax Repundic, No.
82 I5 DEP'T STATE BUL.. 1027, 1928 (1946).

"Art. 4.

80 Art. 6.

Art. 6. 
$25,1945,{ }^{\circ 0}$ Dr. Benes extended similar confiscation to all property with the exception of certain necessities like clothing, tools for trade purpose, et cetera.

In a law of May $16,1946{ }^{61}$ the 1945 decrees were implemented by providing for restitution of property rights held under state administration to "reliable persons in the eyes of the state" who had claims based upon the deprivation of property rights because of "the pressure of occupation or of national, racial or political persecution." This right to restitution did not extend to "persons unreliable in the eyes of the state," 62 a new category broader than mere "enemies of the state" referred to above. In provisions for the presentation of claims against the state administrators of the properties under the r945 decrees, an important requirement was "legitimization" of the claimant, ${ }^{63}$ i.e., proof that the claimant did not fall in the category of the "unreliable." As will be seen, the distinction between the "reliable" and the "unreliable" was perpetuated in the nationalization legislation for purposes of compensation.

Czechoslovakia, like Poland, commenced immediately, i.e., in August 1945, the registration of war damage compensation claims. The provisions of decrees requiring registration of war damages in Bohemia, Moravia, and Silesia ${ }^{64}$ were broad regarding the type of damages to be reported, including damage to health, real and personal property, and earnings by any act of war or occupation or by local Czechoslovak terrorist organizations.

Pursuant to the above decrees, laws were enacted which provided for preliminary allotments to Czechoslovak citizens who were in absolute need or who needed help to restore damaged property and buildings, or for a reduction in real estate taxes. $^{65}$ However, like Poland, Czechoslovakia did not enact any law which specifically provided for rates of compensation to be paid for war damages. At the most Czechoslovak war damage legislation provided for preliminary allotments against a subsequent determination as to the amount of compensation to be granted. ${ }^{66}$ The enactment of compensation legislation has not as yet taken place, presumably on the theory that such legislation, if enacted at all, would be after the coming into effect of the reparation provisions of German and Austrian peace treaties.

By a law of May 15, $1946,{ }^{67}$ Czechoslovakia further adjusted the effects of the Nazi occupation by providing for reporting to the state the status of virtually all property in Czechoslovakia except state owned or administered. A detailed statement was required of the nature of the property, and its history with respect to increment or loss in value as the case might be, between January I, I939 and No-

"The definition of "enemy" also included Czechoslovak citizens who were of German or Hungarian nationality.

${ }^{2}$ Code of Laws and Ondinances of the Czechoslovak Republic, No. 55/46.

${ }^{62}$ Art. 5.

${ }^{4}$ Art. 4.

- Collection of Laws and Ordinances of the Czechoslovak Republic, No. 54/45.

"Id. No. $16 \mathrm{I} / 46$; No. $99 / 46$.

$0 \mathrm{Id}$., No. $16 \mathrm{r} / 46$. Limited to a maximum of $25,000 \mathrm{kcs}$, Art. 6.

${ }^{\circ} \mathrm{Id}$., No. $\mathrm{I} 34 / 46$. 
vember $1_{5}$, I945. ${ }^{68}$ Where the report showed an increase in property value, a severe tax was placed on the increase in value. ${ }^{69}$

Two other phases of relevant Czech legislation are noteworthy as indicating the parallel between Czechoslovakia and Poland. As has been seen, Czéchoslovakia confiscated virtually all agricultural holdings in the Sudeten portion of Western Czechoslovakia. There commenced the forced migration of the divested population to Western Germany. The redistribution of the land in these areas was administered by local agricultural commissions under the direction of the Ministry of Agriculture. This was, primarily, on the basis of colonization, somewhat similar to that carried on in Poland, in which, among other persons, the Czech population was resettled from territory ceded by Czechoslovakia to the Soviet Union. Where land was confiscated in Czechoslovak territory outside of the Sudeten regions, landless workers and small farmers were given preference in the distribution. There also commenced in the Sudeten on a scale unknown in pre-war Czechoslovakia the organization of state-controlled farms. Thus began the genesis of the remarkable expansion of state-owned farms which occurred in Czechoslovakia under the communist government which came into power early in $1948 .^{70}$

There remains to consider the nationalization programs in Czechoslovakia which commenced in October 1945 when the Benes government issued four decrees on nationalization. The first decree ${ }^{71}$ covered almost all major industries such as mining, power, iron and steel, chemicals, armament and munitions, paper, textiles, and leather. Some of the industries, such as mining, power, iron and steel works, and chemical industries, were totally nationalized. Other industries were subject to certain limitations, the most important of which was the number of employees in each individual plant. Enterprises with less than 150 employees were not affected by the nationalization act. On the other hand, all plants employing on an average of more than 500 persons were subject to nationalization. Certain listed enterprises of 200,300 , or 400 employees were specifically brought within the nationalization decree. From time to time thereafter, other decress were promulgated nationalizing specific plants under the decree of October 24, I945.

The second nationalization decree concerned all banks, ${ }^{72}$ the third all private insurance companies, ${ }^{73}$ and the fourth covered the basic branches of the food industry. ${ }^{74}$ It should be noted that in the years which ensued after I945, particularly after the communist coup of 1948 , the area of nationalization was greatly extended. At the outset, however, the problem of compensation, formulated with due regard to the over-all problem of capacity to pay, was handled in a manner similar to that adopted in Poland. The theory of the Benes government was not modified to any significant extent by the communist 'government in the later nationalizations of

\footnotetext{
${ }^{08}$ Art. 2. " $"{ }^{60}$ Art. $38 . \quad{ }^{70}$ See note 6 supra.

71 Code of Laws and Ordinançes qF the Czeghoslovak Republic, No. 100/45.

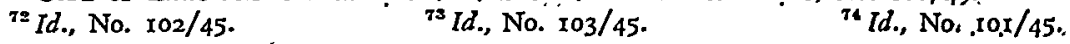


1948. Two prime considerations of major interest in terms of this article were involved.

First, compensation was established at the current value of the property at the time of the nationalization, after the deduction of liabilities. In arriving at the amount of compensation, however, no weight was given to the value of unexploited deposits of raw materials, mining rights, or property devoted to social, educational, and similar purposes. The payment of compensation was to be in the form of Government bonds or, in specified circumstances, cash or other values. The bonds issued by the state for nationalized property were to be amortized by the excess profits of national enterprises. The payment of interest and the amortization of the bonds was guaranteed by the government.

Second, no compensation was to be paid under any circumstances for any nationalized property which at the end of the occupation or later belonged to (I) the German Reich, the Kingdom of Hungary, public persons under German or Hungarian law, the Nazi and Hungarian political parties and related organizations, or German or Hungarian corporations; (2) German and Hungarian nationals, except those loyal to Czechoslovakia who participated in its fight for freedom or suffered under the occupant; (3) natural persons who acted against the authority or unity of Czechoslovakia, its democratic republican form of government, or its safety and defense; or who induced others to act in such ways; or who consciously supported the German or Hungarian occupation authorities; or who earlier (during the period of danger defined by law) promoted Germanization or Magyarization in Czechoslovakia; or who acted against the interests of the Czechoslovak state or of the Czech and Slovak nations; and (4) persons who had tolerated such activities on the part of their business managers or had not exercised sufficient caution and good judgment in the direction of such managers.

If, to the exclusion of the above categories from obligation to pay compensation, there is added the fact that the Czechoslovak Governmnet resisted the payment of compensation of any nature for the holdings of foreign nationals, in the absence of compensatory economic concessions made by the governments of those nationals, ${ }^{75}$ it will be seen how it became possible for Czechoslovakia, in terms of economic planning, to initiate and progressively to extend large-scale nationalization, ending with virtual total nationalization.

\section{IV}

\section{YugosLavis}

As in the case of Poland and Czechoslovakia, among the first formal acts of the post-war government of Yugoslavia was a decree concerning the transfer to state ownership of enemy property. This decree, effective February $6,1945,{ }^{76}$ transferred to state ownership under the management of the state Administration of National

${ }^{75}$ See note 21 supra.

7o Politika (Belgrade), Nov. 22, 1944. Official Gazette, February 6, 1945. 
Property (I) all property of the German Reich and its citizens within Yugoslavia, (2) all property of persons of German race (Volksdeutsche) except those who fought in the National Army of Liberation or Partisan detachments, or those who were citizens of neutral states and did not act as enemies during the occupation; and (3) all property of war criminals and their accomplices without distinction as to nationality, and all property of persons condemned by civil or military courts to loss of property to the benefit of the state. ${ }^{77}$ In addition, administration in trust was taken of property of absent persons who were carried off by enemy forces or fled during the occupation, the property of whom had been transferred to third persons under the pressure of, or by means of forced transfers accomplished by, the Nazi occupation authorities. ${ }^{78}$ This decree applied to all types of property and was administered in conjunction with the basic collaboration law ${ }^{79}$ establishing various defined acts under the occupation as crimes against the State.

In the latter law, effective September I, x945, confiscation of property was among the penalties for those who "economically collaborated with the enemy or occupation authorities by placing their industrial, commercial, transportation or other enterprises or their expert knowledge at the disposal of the enemy for purposes of production nr who themselves produced commodities strengthening the economic power and war potential of the enemy." 80

Effective May 25, r945, the war profits law ${ }^{81}$ provided for the seizure of war profits acquired during the enemy occupation. It applied to any property held on May 9, 1945, over and above what was possessed by the owner on April 6, I941, and derived from purchases or acts performed during that period.

Two agrarian reform laws ${ }^{82}$ enacted on August 5 and August 23, x945, respectively, limited the size of agricultural holdings in order to effect distribution of land to peasants not actually engaged in agricultural pursuits. Large estates and agricultural holdings of banks, enterprises, stock companies, and religious institutions were confiscated without compensation. ${ }^{83}$ On August 16 , 1945, a law on the abrogation of mining privileges ${ }^{84}$ provided that all Yugoslav mines became the property of the state.

So widespread in scope was the application of these penal measures, in which confiscation, without compensation of property, was a common penalty, that even prior to the promulgation of the new Yugoslav Constitution ${ }^{85}$ and the enactment of nationalization laws, between 70 and 80 per cent of Yugoslav industry had passed under state control by this method ${ }^{86}$. With respect to industry, virtually all in-

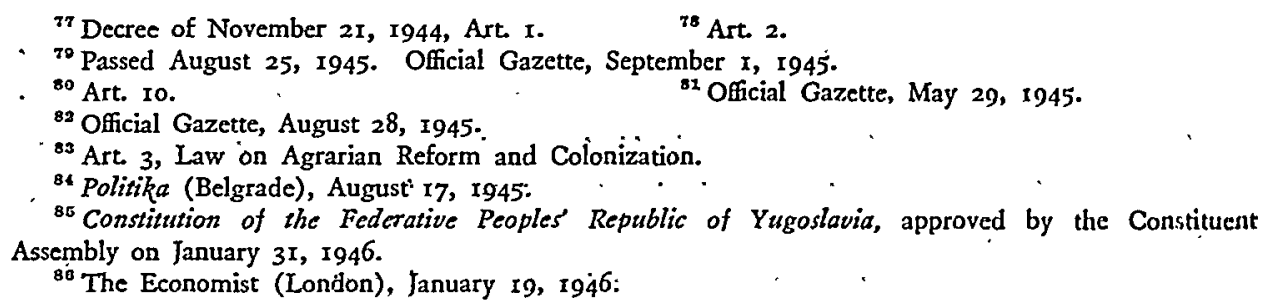


stances of sequestration of property resulted finally in formal confiscation or nationalization. As in Poland and Czechoslovakia, a restitution law, effective May 29, I945, ${ }^{87}$ provided for the restoration of property seized from owners by the occupants or their collaborators on racial, religious, national, or political grounds. All holders of such property were required to turn the property over to the proper units of the Administration of National Property. ${ }^{88}$ Judicial remedies were provided for the return of the property to the owner by the Administration. ${ }^{89}$ In the light of the nationalization laws, which were subsequently enacted, and other economic and tax measures, the amount of property so restored was not of great significance.

The nationalization measures were in two stages. Some 42 categories of private enterprise were nationalized in a law effective December 7, I946.90 Unless a sentence of confiscation had been pronounced against the owner, compensation was payable in the form of government bonds, or, in some cases, in cash as of the value of the net assets on the day the government took over the enterprise. ${ }^{91}$ As to property sequestered prior to its nationalization, the value was taken as of the date the government commenced to administer it. ${ }^{92}$ In April of 1948 an amendment to the basic nationalization law extended the application of that law to virtually all remaining enterprises in Yugoslavia. ${ }^{93}$

A letter addressed to the National Assembly of Yugoslavia by the President of the Economic Council, submitting reasons for the 1948 supplementation of the basic law on nationalization, throws light on a pattern which was pursued in all of the Eastern European countries. ${ }^{94}$ After stating that the proposed nationalization extension would nationalize some 3,100 additional enterprises in Yugoslavia, the President of the Economic Council stated: "Henceforth there will no longer be in Yugoslavia industrial concerns which are not included within the social sector of our economy." The letter then commented on the relationship of war damage and nationalization as follows: ". . the socialist sector of our economy germinated from the confiscation of property belonging to peoples' enemies and war profiteers. These confiscations did not come accidentally; they have not had a class background or revolutionary character. They have not been accidental just as was not accidental the national treason of the exploiting classes. ... The confiscation of property belonging to the peoples' enemies represents the first stage of the socialist sector of our economy, because in the course of the struggle for the national liberation, profound revolutionary social changes took place in our country."

Yugoslavia, in a decree of April ro, r945, ${ }^{95}$ established a War Damage Commission for the purpose of reporting and classifying war damages. The categories of war

\footnotetext{
${ }^{87}$ Politika (Belgrade), February 18, 1946. Law on Abandoned and Enemy-Alienated Property, passed May 24, 1945.

${ }^{88}$ Art. 2.

0.) Politika (Belgrade), December 6, 1946 .

92 Art. 9.

-4 Barba (Belgrade), April 29, 1948.

${ }^{80}$ Art. 7.

21 Arts. Io and II.

${ }^{\text {Q3 }}$ Politika (Belgrade), April 29, I948.

os Official Gazette, No. 20, April 10, 1945.
} 
damage were defined in extremely broad terms. ${ }^{90}$ As yet no war damage compensation legislation has been enacted in Yugloslavia and it is generally understood that the registration was for the purpose of compiling a reparations account to be utilized by Yugoslavia in connection with reparation provisions of World War II peace treaties.

\section{V}

Certain implications may be drawn from the economic history of the post-war years in Eastern Europe. These implications are of serious import and should be considered by students of the economic and political consequences of modern war. World War II demonstrated again that the structure of property rights and the economic fabric of societies are greatly weakened by war. Europe as a whole, before the Marshall Plan, faced a common problem of reconstruction and rehabilitation. The Eastern European countries, taking the path of non-Marshall Plan participation, moved step by step to the ultimate logic of total nationalization. In the 1945 beginnings, the liberated governments assumed the roles of administrator or sequestrator of economically significant properties pending reestablishment of the new economy. An important element in national planning for greater state ownership and control, where such ownership and control were deemed necessary for economic stability, was the question of the restoration of the rights of former property holders and the legal obligation to compensate. Clearly, conversion of economies from private enterprise to national ownership, if pursued in accordance with traditional principles of compensation, would entail prohibitive cost. The necessity of extending national ownership irrespective of cost dominated the economic thought of the liberated governments, and this was met, in large degree, by utilizing on a large scale the technique of confiscation without compensation. Superimposed on this technique were the policy of local compensation for nationalized property in long term blocked currency obligations and the policy of resistance to the nationalization claims of foreign nationals. Restitution legislation, the converse of confiscation legislation, while necessary in theory to justify confiscation, proved of little practical meaning in practice, given the necessity of large private expenditure for war damage repair and heavy taxation, if return of the property were asked. Even as to the early noncommunist governments of Poland and Czechoslovakia, large sectors of the economy came under government ownership and control without compensation. Intermediate stages of administration or sequestration for temporary purposes quickly merged into state ownership or redistribution of property rights. "When as a result of the political pressures asserted by the Soviets, following the basic political decision not to permit participation in the Marshall Plan, communist governments took over in Poland and Czechoslovakia, the process of state ownership and control had already far advanced due to the inexorable logic of the damage, disruption, and chaos caused by World War II.

${ }^{20}$ Id., No. 44, June 26, I9,45. 